\title{
ASPECTE PRIVIND CONTRACEPŢIA ŞI SĂNĂTATEA REPRODUCERII LA ADOLESCENTELE OBEZE
}

\author{
Laura-MihaelaTrandafir ${ }^{1}$, Madalina Ionela Chiriac ${ }^{2}$, Oana Teslaru ${ }^{3}$, \\ Ingrith Miron ${ }^{4}$, Oana Chirila ${ }^{5}$, Smaranda Diaconescu $^{6}$ \\ ${ }^{1}$ Clinica III de Pediatrie, Spitalul Clinic de Urgență pentru Copii ,, Sfânta Maria“", \\ Universitatea de Medicină şi Farmacie „, Grigore T. Popa “, Iaşi \\ ${ }^{2}$ Clinica de Endocrinologie, Spitalul Clinic Județean de Urgență Cluj-Napoca, \\ Cluj-Napoca \\ ${ }^{3}$ Parodontologie, Universitatea de Medicină şi Farmacie ,, Grigore T. Popa“, Iaşi \\ ${ }^{4}$ Clinica IV de Pediatrie, Spitalul Clinic de Urgență pentru Copii ,, Sfânta Maria “, \\ Universitatea de Medicină şi Farmacie ,, Grigore T. Popa “, Iaşi \\ ${ }^{5}$ Psiholog, Clinica de Pediatrie, Spitalul Clinic de Urgență pentru Copii ,, Sfânta \\ Maria “, Iaşi \\ ${ }^{6}$ Clinica V de Pediatrie, Spitalul Clinic de Urgență pentru Copii ,, Sfânta Maria “, Iaşi
}

\begin{abstract}
REZUMAT
Sarcinile nedorite reprezintă o problemă serioasă a morbidității în anii adolescenței, utilizarea contraceptivelor fiind un element de prevenție la această vârstă. Adolescentele obeze tind să folosească mai puțin metode contraceptive decât cele cu o greutate normală, excesul de greutate fiind des folosit ca motiv pentru neutilizarea metodelor contraceptive. Acestea au o probabilitate crescută de a avea sarcini nedorite asociate cu toate riscurile gravidității şi naşterii la o vârstă fragedă, având totodată nevoie de metode mai sigure şi eficiente de contracepție. Scăderea numărului de sarcini la această categorie este o prioritate a sănătății publice şi impune detectarea adolescentelor aflate în categoria de risc. Deşi există opinii împotriva contracepției din cauza efectelor adverse, Organizația Mondială a Sănătății promovează ideea că adolescenții pot utiliza orice metodă de contracepție datorită avantajului de a preveni sarcinile nedorite, care depăşeşte riscurile utilizării lor.
\end{abstract}

Cuvinte cheie: adolescență, obezitate, sarcină, contracepție

\section{INTRODUCERE}

Obezitatea la vârsta adolescenței a atins nivelul unei epidemii, datele actuale aratând că în ultimii 30 de ani, procentul de adolescenți obezi a crescut de peste patru ori la nivel mondial. În Statele Unite ale Americii, la grupa de vârstă 12-19 ani, rata obezității a crescut de la 5\% în anul 1980 la 21\% în anul 2012 (1,2). Conform Raportului de sănătate a copiilor şi tinerilor din România (2014) privind cauzele de îmbolnăvire pentru anul şcolar 2012/2013, obezitatea de cauză neendocrină se situează pe locul doi, după viciile de refracție $(5,04 \%)$, urmată de patologia coloanei vertebrale $(1,9 \%)$, hipotrofia ponderală $(1,71 \%)$ şi sechelele de rahitism $(1,58 \%)$. Conform aceluiaşi raport, 1 din 3 copii cu vârste cuprinse între 6 şi 9 ani sunt supraponderali sau obezi. Incidența supraponderalităţii (inclusiv obezitatea), la copiii de 11-13 ani variază de la 5\% la peste $25 \%$ (3).

Adolescenţii cu exces ponderal şi obezitate se confruntă cu reale probleme de sănătate din punct de vedere medical, psihologic şi reproductiv. Intervenția nutrițională precoce este esențială pentru a preveni comorbiditățile asociate obezității, apărute atât pe termen scurt, dar şi pe termen lung. Adolescența este o perioadă de tranziţie caracterizată de schimbări la nivel fizic, comportamental şi de personalitate. Adolescentul devine preocupat de propria imagine şi de poziţia sa în raport cu cei din jur. Obezitatea la această vârstă are consecințe grave asupra conturării autonomiei, identităţii şi adaptării 
sexuale a viitorului adult. Pe lângă multiplele complicații organice (cardiovasculare, endocrine, gastrointestinale, pulmonare şi osteoarticulare), complicațiile psihosociale ale obezității sunt la fel de importante la această vârstă. Depresia, stima de sine scăzută, prejudecățile societății legate de obezitate sunt factori care îngreunează gestionarea greutății de către adolescentul obez. Prin urmare, familia, şcoala, societatea trebuie să identifice şi să sprijine adolescenții cu probleme nutriționale. Adolescentul depinde de colaborarea familia, cu profesorii, cu psihologul şcolar şi medicul pentru a aborda atât problemele legate de consilierea nutrițională, cât şi despre viața sexuală şi contracepție, prevenirea bolilor cu transmitere sexuală şi a consumului de droguri.

\section{Obezitatea asociată în sarcină şi perturbările psihoemoționale care survin la adolescente}

Datele din literatură arată că peste $60 \%$ din copiii supraponderali înainte de pubertate vor fi supraponderali la maturitate, ceea ce va conduce la dezvoltarea de boli cronice, cum ar fi bolile cardiovasculare şi diabetul de tip 2. $25 \%$ dintre copiii de 15 ani au avut relații sexuale şi, în unele țări, mai mult de 30\% nu folosesc prezervative sau orice altă formă de contracepție, consecințele fiind bolile cu transmitere sexuală şi sarcinile nedorite la adolescente (3).

Sarcinile nedorite reprezintă o problemă serioasă a morbidității în anii adolescenței, utilizarea contraceptivelor fiind un element de prevenție la această vârstă $(4,5)$.

Riscul de deces al mamei minore este de patru ori mai crescut printre adolescentele cu vârsta mai mică de 16 ani, în comparație cu femeile cu vârsta peste 20 de ani. Până la $65 \%$ dintre femeile care prezintă complicații obstetricale au prezentat sarcini în perioada adolescenței (6).

Sarcina la vârsta adolescenței este o situație nedorită, care pune viitoarea tânără mamă în situații deosebite şi o expune unor riscuri cu care mamele de vârsta adultă se confruntă mai rar. Cauzele apariției sarcinilor la adolescente sunt condițiile socioeconomice precare, nivelul educațional scăzut, căsătoriile precoce, în special în rândurile unor etnii şi apartenențe religioase, actul sexual precoce neprotejat, partenerul mai vârstnic, abuzul, violul, consumul de alcool şi de droguri, influenţa mediului şi a mass-mediei. Sarcina la vârsta adolescenței implică un risc crescut de complicații, precum naşterea unui copil mort, naşterea prematură, greutatea mică la naştere, asfixia neonatală, mortalitate infantilă în prima săptămână a primei luni de viață (7).
Principala complicație obstetricală care survine la adolescente este reprezentată de naşterea prematură, mai ales în cazul în care intervalul dintre menarhă şi concepție este scurt. (8)

Problemele psihoemoționale care apar pe fondul sarcinii la vârsta de adolescent au fost raportate încă din 1980. Faigel raporta efectele psihoemoționale asupra copiilor născuţi la vârsta adolescenței; 20 de bărbați şi femei care au devenit părinţi în adolescență au fost intervievați 17 până la 24 de ani mai târziu. Toate sarcinile survenite în adolescență au fost mai întâi văzute ca o disonanță sau nereuşită de a stabili o relaţie părinte-copil din cauza comportamentului rebel în timpul adolescenței şi implicit a copilului născut în propria lor adolescență. Copiii părinților adolescenți au avut un comportament adecvat în timpul copilăriei, dar odată ajunşi la vârsta adolescenței, având activităţi specifice vârstei (ieşeau în oraş), acestea din urmă au fost interpretate de părinți ca negative, şi chiar în pericol de a repeta ,greşeala“ parentală. Mamele adolescente s-au dovedit a-şi spiona în mod deschis fiicele, exprimâdu-şi neîncrederea în relațiile lor heterosexuale. Toți părinții au fost în imposibilitatea de a discuta despre sexualitate cu copiii lor (9).

Condițiile inadecvate de dezvoltare intrauterină, prematuritatea, dificultățile la naştere, precum expulzarea dificilă, greutate mică la naştere, anemia din sarcină şi malformații au fost descrise împreună cu întârzierea dezvoltării psihosomatice, dizabilitățile de comportament şi de limbaj că pot apărea la copil precum complicații pe termen lung. Unele studii asociază sarcina din adolescență cu o evoluție predominant negativă, putând fi atribuită unor factori socio-demografici, cum ar fi sărăcia, nivelul scăzut de educație, îngrijirea prenatală inadecvată şi statusul necăsătorit $(10,11)$.

Conform „Ghidului pentru adolescentele însărcinate“ (Adolescent Pregnancy Guidelines) al Societății Canadiene de Ginecologie, la nivel modial, s-au înregistrat, anual, 14 milioane de naşteri la mame minore, cu vârsta cuprinsă între 14 şi 19 ani. (12)

\section{Contracepția şi eficacitatea utilizării la adolescentele obeze}

OMS promovează ideea ca adolescenții pot folosi orice metodă de contracepție şi că ar trebui să aibă acces la o varietate de metode contraceptive. Vârsta nu este un impediment în nici o variantă de contracepție. Deşi există opinii împotriva contracepției orale din cauza efectelor adverse (13) (greața, creştere în greutate, dismenoree, uneori agrava- 
rea acneei), avantajele acestor metode ar trebui luate în considerare pentru a evita sarcinile nedorite la vârste tinere (6). OMS recomandă diferite metode pentru prevenirea sarcinilor la adolescente, încercând totodată să elimine barierele financiare legate de utilizarea contraceptivelor şi să îmbunătățească accesul la informații despre contraceptive (14).

Contracepția la mamele adolescente este necesară datorită existenței unui risc semnificativ de repetare a sarcinii, cu $25 \%$ mai crescut în următorii 2 ani de la naştere. La adolescentele postpartum, prevenirea sarcinilor ulterioare se poate realiza prin metode de contracepție reversibilă cu acțiune prelungită, cum ar fi DMPA (acetat de medroxiprogesteron) şi dispozitivele intrauterine, având o rată de succes mult mai înaltă decât metodele de contraceptie pe termen scurt, cum ar fi contraceptive orale, contraceptiv de tip patch sau metodele de barieră (diafragmă). Metode de contracepție reversibilă cu acțiune prelungită sunt aprobate în mod special pentru adolescente de Congresul American de Obstetrică şi Ginecologie. Contracepția imediată postpartum, cu iniţierea DMPA postpartum, plasarea DIU în momentul livrării sau plasarea de implant contraceptiv înainte de externare au dus în mod semnificativ la reducerea ratelor de sarcină re-petată (12).

Într-un studiu realizat de Thurman şi colaboratorii s-a observat faptul că la 14,2\% dintre adolescente care au utilizat DMPA a survenit o sarcină un an mai târziu, comparativ cu $29,7 \%$ şi $31,8 \%$ dintre adolescentele care utilizau ca metode de contracepție contraceptivele orale şi patch-urile (15).

Utilizarea contracepției sigure şi eficiente este esențială pentru prevenirea sarcinilor nedorite, în special în rândul adolescenților. În momentul consilierii adolescentei obeze cu privire la contracepție, trebuie luate în considerare mai multe aspecte: modul în care surplusul de greutate afectează siguranța şi eficacitatea diferitelor metode de contracepție şi efectele contraceptivelor asupra greutății corporale (16-18).

Un studiu longitudinal efectuat de Chang şi colaboratorii realizat în rândul adolescentelor cu vârste cuprinse între 18 şi 19 ani privind comportamentul sexual a arătat că adolescentele obeze au fost mai puțin dispuse să utilizeze metode contraceptive şi mai puţin probabil să le folosească în mod consecvent, în comparaţie cu adolescentele normoponderale. Astfel datele raportate sugerează că obezitatea poate fi considerată un factor asociat comportamentului sexual al adolescentelor supraponderale/obeze (19).
Conform ghidului de utilizare a contracepției la adolescente din SUA, nevoile sănătății şi comportamentul sexual al adolescentilor cu obezitate sunt substanțial similare cu cele ale persoanelor cu greutate normală. În privința abordării contracepției, este important de menționat că obezitatea şi efectele conexe endocrine pot să influenţeze eficacitatea şi efectele adverse ale contraceptivelor. De exemplu, au fost raportate un număr redus de sarcini survenite la un interval de timp scurt printre utilizatoarele de contraceptive de tip plasturi transdermic având o greutate corporală mai mare de $90 \mathrm{~kg}$. Raportul Organizației Mondiale a Sănătății şi al Centrelor pentru Controlul şi Prevenția Bolilor arată că datele sunt limitate şi inconsecvente despre eficacitatea contraceptivelor orale combinate (COC). Mai mult, acestea variază în funcție de greutate corporală sau indexul de masă corporal- IMC. S-a raportat faptul că femeile obeze care folosesc COC, inel vaginal sau dispozitive intrauterire nu suferă modificări ale greutății corporale după inițierea COC comparativ cu cele normoponderale. În contrast, s-a observat că adolescentele obeze care utilizează DMPA sunt mai probabil predispuse să câş̧ige în greutate comparativ cu cele care nu utilizează DMPA, dar greutatea corporală se modifică în sens pozitiv la adolescentele obeze care utilizează COC şi la cele normoponderale care utilizează DMPA. Numărul de adolescenți la care se efectuează proceduri de chirurgie bariatrică este în creştere, iar aceştia au nevoie de o metodă de contracepție eficientă. Datele relevă o îmbunătățire a fertilității în cuplu postchirurgical, cu potențial de a scădea eficacitatea contraceptivelor datorată sindromului de malabsorbție, vărsăturilor şi diareei. Se recomandă amânarea sarcinii timp de cel puțin 12 luni după procedura chirurgicală bariatrică (20).

Într-o mică populație de adolescenți care s-au prezentat la spital cu trombembolism venos (TEV) asociat contracepției, s-a observat că majoritatea aveau multipli factori de risc pentru TEV. Au fost înrolate în studiu 26 de paciente tinere cu vârsta între 12-21 ani, admise pentru TEV legate de contracepția hormonale. Din 57 de cazuri de TEV revizuite, 26 au fost identificate ca TEV legate de contracepție. 96\% dintre pacienți au avut cel puțin un factor de risc suplimentar pentru TEV, iar $42 \%$ dintre pacienți au avut 2 sau mai mulți factori de risc. $50 \%$ dintre pacienți au avut un IMC $\geq 25 \mathrm{~kg} / \mathrm{m}$. $35 \%$ dintre pacienți au avut un istoric familial pozitiv de TEV la rude de gradul I sau II. 27\% dintre pacienți au fost ulterior diagnosticați cu o trombofilie moştenită, dintre care 5 au avut un istoric familial pozitiv. Obezitatea a fost cel mai frecvent 
factor de risc suplimentar (50\%) identificat în populația din studiu. Mai multe cercetări sunt necesare cu privire la impactul obezității asupra TEV legate de contracepție la adolescente, şi dacă prezența obezității ar putea să influențeze practicile de screening pentru trombofilie înainte de a prescrie metode contraceptive (21).

\section{Obezitatea şi perturbările endocrine care survin la adolescente}

În prezent, obezitatea reprezintă o reală problemă de sănătate publică. Prin urmare, scăderea numărului de sarcini la adolescentele obeze este o prioritate a sănătății publice şi impune identificarea adolescentelor aflate în categoria de risc.

Greutatea excesivă este considerată un motiv de eficacitate scăzută a contraceptivelor orale la vârsta adolescenței. Țesutul adipos este considerat un veritabil organ endocrin. Adipozitatea în exces afectează fertilitatea, din cauza faptului că măreşte riscul de cicluri menstruale neregulate şi de apariţie a sindromului ovarului polichistic (22). Obezitatea viscerală este răspunzătoare de nivelurile crescute de androgeni care afectează, de asemenea, şi funcția ovariană (23).

Rezistența la insulină legată de obezitate este responsabilă de disfuncții ovulatorii şi scăderea nivelului hormonului sexual de legare a globulinei (SHBG - sex hormone binding globulin). SHGB este o proteină plasmatică implicată în legarea specifică a hormonilor androgeni şi a estradiolului circulant. Este sintetizată la nivel hepatic, iar secreția sa este controlată prin mecanism de feed-back de nivelurile circulante de androgeni şi estradiol. Concentrația SHBG influențează atât biodisponibilitatea tisulară a steroizilor sexuali, cât şi balanța estroandrogenică. Nivelurile crescute de androgeni inhibă sinteza SHBG, în timp ce nivelurile crescute de estradiol stimulează sinteza de SHBG. Astfel, în sindromul ovarelor polichistice, obezitate, hipotiroidie concentrațiile de SHBG sunt scăzute. Cu toate acestea, este important de menționat că majoritatea adolescentelor obeze vor continua să aibă ovulația regulată. Chiar dacă ovulația nu apare în fiecare lună, există un risc crescut de sarcină nedorită (24).

\section{DISCUȚII}

Studiile arată că obezitatea poate fi un important factor de risc, în asociere cu comportamentul sexual al adolescenților. Femeile care au avut sarcini încă din adolescență au risc mai mare de a deveni obeze mai târziu în viață. Complicații precum diabetul gestațional, hipertensiunea arterială, hipercoagulabilitate, făt mort in utero sunt mult mai frecvent întâlnite la adolescentele obeze însărcinate. De asemenea, copiii acestora, nou-născuții, din cauza patologiei neonatale, necesită spitalizare în unităţile de terapie intensivă neonatală, comparativ cu nou-născuţii din mame cu status nutriţional normal. Înțelegerea comportamentului sexual în corelație cu greutatea adolescentei este esențială, întrucât aceste riscuri implică atât mamele, cât şi copii (25-27).

În afară de problemele medicale (apărute atât la copil cât şi la mamă) şi socio-economice pe care le ridică sarcina la vârsta adolescenței, un aspect deloc de neglijat este reprezentat de tulburările psihologice. Minorele însărcinate prezintă sentimente de incertitudine şi nesiguranță care generează anxietate, insomnie, sentimente intense de ambivalenţă şi confuzie, precum şi unele simptome depresive, sentimente de tristețe, gânduri de sinucidere şi iritabilitate. Astfel, tulburările somatice, anxietatea şi insomnia, depresia severă, sentimentele de vinovăție, stima de sine scăzută vor duce la izolare familială şi socială, cu abandon şcolar, creând un cerc vicios, care va agrava si mai mult problemele psihosociale şi psihiatrice. În ceea ce priveşte manifestările depresive la mamele adolescente, s-a observat că adolescentele cu vârsta cuprinsă între 15 şi 17 ani au fost de două ori mai deprimate comparativ cu mamele adulte, iar simptomele de depresie severă au fost mai frecvent întâlnite la această grupă de vârstă comparativ cu grupa de vârstă 19-20 ani $(28,29)$.

Toate adolescentele active sexual trebuie să primească consiliere în ceea ce priveşte contracepția. Fetele adolescente obeze au un risc rescut de sarcini nedorite, cu toate riscurile aduse de o sarcină mult prea timpurie, având nevoie de o metodă de contracepție sigură şi eficientă (30).

Este cunoscut faptul că obezitatea este un factor de risc în hiperplazia endometrială şi în cancerul endometrial. Contracepția hormonală ofera protecție endometrului, fiind asociată cu o incidența scăzută în cazul acestor patologii (31-34).

Anticoncepționalele s-au dovedit sigure şi eficiente, mai ales în cazul adolescentelor. Încurajarea fetelor obeze să utilezeze anticoncepționale orale ar trebui să continue, chiar dacă au fost raportate câteva cazuri eşuate (35). De asemenea, literatura de specialitate arată că adolescenții cu un stil de viață sănătos care utilizează anticoncepționale hormonale orale, dispozitive intra-uterine, sau alte metode contraceptive nu devin supraponderale sau obeze (17). În special pentru anticoncepționalele hormo- 
nale orale, este clar evidențiat că nu există diferență de greutate între o femeie care foloseşte şi o femeie care nu foloseşte acest tip de medicație (36). Chiar dacă folosirea anticoncepționalelor orale nu determină creşteri în greutate, utilizarea acestora poate determina unele schimbări, ca de exmplu: creşterea procentajului de grăsime în corp şi scăderea procentajului de masă musculară (37). De asemenea, a fost observată şi o scădere a performanțelor în timpul activităților fizice, după 3 ani de utilizare continuă a anticoncepționalelor orale, deci creşterea în greutate a fost greşit atribuită metodelor contraceptive, în loc să fie atribuită schimbării modului de viață, cu abordarea unui stil de viață sedentar (38).

Când se discută despre metode contraceptive hormonale orale, trebuie luate în calcul şi riscurile adverse, cum ar fi creşterea riscului de tromboză venoasă. Obezitatea în sine este asociată cu risc crescut de tromboză venoasă şi embolie pulmonară la femei, în principal în primul an de utilizare a contraceptivelor orale $(39,40)$.

\section{CONCLUZII}

Obezitatea la vârsta adolescenței reprezintă o problemă de sănătate publică cu multiple comorbidități. Promovarea unor strategii de sănătate publică bazate pe promovarea unui stil de viață sănătos şi practicarea regulată a activității fizice reprezintă o prioritate la nivel național în vederea prevenirii bolilor cronice netransmisibile. $\mathrm{O}$ bună cunoaştere a metodelor contraceptive va ajuta medicul pediatru atât în promovarea unei vieți sexuale sănătoase, cât şi în rezolvarea problemelor ginecologice întâlnite la adolescente. Statisticile arată că mai mult din jumătate dintre adolescenți îşi încep viaţa sexuală în timpul liceului, majoritatea nebeneficiind de acces la protecție adecvată împotriva sarcinilor nedorite şi bolilor cu transmitere sexuală. În concluzie, abordarea multidisciplinară (pediatru, ginecolog, nutriționist, psiholog) pare a fi o soluție optimă pentru această categorie de adolescente. 